\title{
CHIRONOMID RESEARCH IN NORTHERN PATAGONIA
}

\author{
Donato, Mariano ${ }^{1}$, Julieta Massaferro ${ }^{2} \&$ Stephen J. Brooks ${ }^{3}$ \\ ${ }^{1}$ Laboratorio de Sistemática y Biología Evolutiva (LASBE), Museo de La Plata, Paseo del Bosque s/n \\ (1900), La Plata,Argentina, mdonato@fcnym.unlp.edu.ar \\ ${ }^{2}$ Laboratorio de Biodiversidad, INIBIOMA - CONICET, San Martín 24, (8400) Bariloche, Argentina, \\ julimassaferro@crub.uncoma.edu.ar \\ ${ }^{3}$ Department of Entomology, Natural History Museum, London SW7 5BD, United Kingdom, \\ sjb@nhm.ac.uk
}

Patagonia is the southernmost territory of South America and was traditionally considered as belonging to the Neotropical region (Sclater 1858, Wallace 1876). Based on these zoogeographic schemes, the Argentinean biogeographer Raul Ringuelet (1961) divided Patagonia into the Araucanian Subregion, characterized by dominance of Austral or Notogeic fauna, and the Andean-Patagonian Subregion, having a dominant mixture of Notogeic, Brasilic, and Nearctic elements. Later, Cabrera \& Willink (1973) proposed a biogeographic scheme for South America and the Caribbean in which the Andean-Patagonian region was part of the Neotropical region and Araucania. They named the region the SubAntarctic province, which was part of the Antarctic region and was based on the floristic and faunistic affinities of southwestern Patagonia with Antarctica, Australia and New Zealand. Further biogeographic schemes considered Patagonia as a part of a Holantarctic region (Takhtajan 1986) or Sub-Antarctic subregion and Patagonian subregion of the Andean Region (Morrone 2001). The extraordinary amount of different biogeographic schemes reflects the complexity of the affinities of the biota of Patagonia.

From an ecological perspective, Patagonia is highly influenced by the Andes cordillera. The climate in western Patagonia is cool-temperate but rainfall decreases drastically eastwards towards the steppes. Therefore, climate and soil conditions make Patagonia extremely waterlimited and this is reflected in the aquatic ecosystems. The western part of Patagonia is covered by two eco-regions. The Valdivian temperate forest, covering a narrow continental strip between the western slope of the Andes and the Pacific Ocean, and running from $35^{\circ} \mathrm{S}$ to $48^{\circ} \mathrm{S}$, is characterized mainly by deciduous and evergreen forests and Valdivian rainforest. The eastern part of Patagonia is distinguished (from north to south) by the Argentinean Monte, dominated by scrub vegetation, the Patagonian steppe, with shrub vegetation, and the Patagonian grassland, with grass-steppe interspersed with shrubs (Olsen et al. 2001).

The habitats and communities in Patagonian freshwater ecosystems have been modified by different extents and causes. The construction of dams and the resulting reservoirs to regulate rivers and control floods have modified seasonal flow patterns, thus affecting environmental conditions for most species. As a result, lotic watercourses have become lentic environments. Other important alterations of the physical environment in Patagonia are the consequence of mining activities, urban development and degradation derived from tourism. Ironically, wetlands are essential for sustaining biodiversity and wildlife. Patagonian wetlands present complex aquatic communities and provide habitat for threatened species and a high number of endemic species.

The freshwater insect biodiversity of Patagonia is poorly known and knowledge is constrained by a lack of adequate identification guides and reference collections. In addition, there is poor public understanding of the importance of wetlands for biodiversity. In order to address these issues, a three year Darwin Initiative project, entitled "Capacity Building for Aquatic Insects in Patagonia” and supported by the Department for Environment, Food and Rural Affairs (Defra, UK), began in 2006. The study area is the Nahuel Huapi National Park (NHNP) in northern Patagonia, Argentina. NHNP covers $7050 \mathrm{~km}^{2}$ of Patagonian steppe, temperate deciduous forest and Valdivian rainforest. The latter ecosystem is recognised as one of the most threatened eco-regions in the world by the Global 2000 initiative launched by WWF and the World Bank. The main objectives of the Darwin Initiative project are to increase knowledge of freshwater insect biodiversity; to promote conservation of the various freshwater ecosystems in this protected area; and to communicate, share and educate citizens in different aspects of biodiversity. The project brings together a team of British and Argentinean scientists from the Natural History Museum 
London, The Natural History Museum La Plata, The Institute of Limnology La Plata, The University of Patagonia in Esquel, The Central Regional University at Bariloche and the National Parks Administration Bariloche.

A key task for the team is to study the major freshwater insect groups in NHNP including Chironomidae, Ceratopogonidae and Simulidae (Diptera); Plecoptera; Ephemeroptera; Odonata; Trichoptera; and aquatic Coleoptera. With invaluable logistics support from the park rangers and other NHNP staff, more than 200 sites have been sampled covering the various freshwater environments represented in NHNP. The sampling methods included Malaise trap, light trap, sweep net, drift net and kick sample. Taxonomic, ecological and distributional data resulting from this collecting effort is being entered into a database of freshwater insects from NHNP. The species distribution data will be linked to a vegetation classification and the physical and chemical attributes of the water bodies, using GIS and digital imaging, and will be used to model freshwater insect data spatially and create a biodiversity data repository, the first of its kind in Patagonia. Another important project goal was addressed by building infrastructure in NHNP to provide a wetland interpretation centre and laboratory where tourists, sport anglers, students and researchers can study freshwater insects and understand their role in freshwater ecosystems.

\section{Patagonian chironomid fauna}

The first records and knowledge of Chironomidae from Patagonia are due to the invaluable work of the English entomologist Frederick Wallace Edwards (1888-1940). To obtaining collections of insects from the southern Andes, a joint expedition was arranged in 1926 by the British Museum of Natural History and the Bacteriological Institute of the National Department of Hygiene of Argentina. Edwards went to collect for the British Museum and Mr. Raymond C. Shannon for the Argentine Government. At the end of the field trip, they collected collections of over 20000 insects each one (Edwards 1927). After the study of the material collected, Edwards published in 1931 published the chapter referred to Chironomidae as a part of the book "Diptera of Patagonia and South Chile" and he described 71 new species and gives the foundation of the chironomid Patagonian knowledge.

Preliminary data on Chironomidae collected during the project, supplemented by examining collections made by earlier entomologists and literature searches, has shown that the chironomid fauna of NHNP includes 104 species in 48 genera and 6 subfamilies. Analysis of subfossil larvae from lake sediments collected in NHNP include 52 morphotypes in 36 genera and 4 subfamilies (Donato et al. 2008). The number of chironomid species found in NHNP constitutes a relatively high proportion of the chironomid diversity of Patagonia. Nine subfamilies are recorded from this region, including the monotypic subfamily Chilenomyiinae which is endemic for the area. Of the 111 known genera from South America, 53 are present in the study area. Approximately $20 \%$ of the genera recorded from Patagonia are endemic to the region. One hundred and seventy seven species of Chironomidae have been recorded from Patagonia, 98\% of them are endemic, $3 \%$ are considered nomina dubia and about $17 \%$ require revision since their systematic position is doubtful. Taking the Andean cordillera as a boundary, 55 species are endemic to the eastern side, 57 are endemic to the western side and 65 are common to both sides. The original descriptions of the chironomid species from Patagonia are based mainly on males $(n=58)$ or males and females $(n=43)$ which represents $57 \%$ of the total. The rest of the species have been described using different combinations of stages from their life cycle (Donato et al., 2009). The Patagonian chironomid fauna shows affinities with the Australasian region (i.e. with a strict transantarctic distribution) exemplified by the Chironominae genera Megacentron Freeman and Riethia Kieffer, the Podonominae genus Rheochlus Brundin, and the Orthocladiinae genera Austrocladius Freeman, Botryocladius Cranston \& Edwards, Parapsectrocladius Cranston, Rhinocladius Edwards and Stictocladius Edwards. Based on the material collected, mounted and studied so far during the last three years, we have found 16 new species that are waiting for more data (mostly concerning their immature stages) before they are described.

\section{References}

Cabrera, A.L. \& Willink, A. 1973. Biogeografía de América Latina. Monografía 13. Serie de Biología. Secretaría General de la Organización de los Estados Americanos. Washington DC. USA. 120 pp.

Donato, M., Massaferro, J. \& Brooks, S.J. 2008. Chironomid (Chironomidae: Diptera) checklist from Nahuel Huapi National Park, Patagonia, Argentina. Revista de la Sociedad Entomologica Argentina 67: 163-170. 
Donato, M., Massaferro, J. \& Brooks, S.J. 2009. Estado del conocimiento taxonómico de la fauna de Chironomidae (Diptera: Nematocera) de la Patagonia [Current state of the taxonomic knowledge of the Chironomidae fauna (Diptera: Nematocera) of Patagonia]. Revista de la Sociedad Entomologica Argentina 68 (1-2): 187-192.

Edwards, F.W. 1927. Insect collecting in the Southern Andes. Natural History Magazine 1: 111-125.

Edwards, F.W. 1931. Chironomidae. Diptera of Patagonia and South Chile, based mainly on material in the British Museum (Natural History). Part 2, Nematocera. London: Printed by Order of the Trustees. pp. 233- 331.

Morrone, J.J. 2001. Biogeografía de América Latina y el Caribe. M\&T-Manuales \& Tesis SEA, vol. 3. Zaragoza, 148 pp.

Olson, D.M., Dinerstein, E.,Wikramanaya, E.D., Burgess, N.D., Powell, G.V.N., Underwood,
E.C., D’amico, J.A., Itoua, I., Strand, H.E., Morrison, J.C., Loucks, C.J., Allnutt, T.F., Ricketts, T.H., Kura, Y., Lamoreux, J.F., Wettengel, W.W., Hedao, P. \& Kassem, K.R. 2001. Terrestrial Ecoregions of the World: A New Map of Life on Earth. Biosciences 51 (11): 933-938.

Ringuelet, R.A. 1961. Rasgos fundamentales de la Zoogeografía de la Argentina. Physis 22 (63): 151-170.

Sclater, P.L. 1858. On the general geographical distribution of the members of the class Aves. Zoological Journal of the Linnean Society 2: 130-145.

Takhtajan, A. 1986. Floristic regions of the world. University of California. Berkeley, USA. 522 pp.

Wallace, A.R. 1876. The Geographical Distribution of Animals. Macmillan, London. 